\title{
PATTERN OF RETAIL MARKETING
}

(A case study in Kakinada city only).

\author{
Dr.B.Charwak \\ Lecture, \\ School of Management Studies, \\ Jawaharlal Nehru Technological University Kakinada.
}

\begin{abstract}
This paper attempts to present the retail trends in India's economic growth which has accelerated significantly over the past two decades and so, too, has the spending power of its citizens. Real average household disposable income has roughly doubled since 1985 . With rising incomes, household consumption has soared and a new Indian middle class has emerged. The Indian consumer is changing rapidly. The average consumer today is richer, younger and more aspirational in his/her needs than ever before. Consumers now value convenience and choice at par with getting value for their hardearned money. Retailing is the world's largest private industry with total sales of \$6.6 trillion. In India, the industry is large, accounting for around $10 \%$ of GDP which is the second largest after agriculture. India has one of the highest densities of retail outlets in the entire world. This paper used spss statistical tools to analysis and reviles the data.
\end{abstract}

\section{KEYWORDS}

Organized Retailing, Smaller cities, Buying Behaviour, Customer satisfaction

\section{The concept of the Retailing}

Retailing influences standards of living, life style and daily survival of the human beings straightforwardly and obliquely by marketing available multi-level of goods and services at reasonable price.

Retailing consist the sale of goods or merchandise from a fixed location i.e. a departmental store or by post, in small or individual lots for direct consumption by the purchaser. Retailing may include subordinate services such as delivery. A retailer buys products in large quantities from manufacturers or importers, either directly or through a wholesaler and then sells small quantities to the end-user. Retail establishments are often called shops or stores. Retailers are at the end of the supply chain. Manufacturing marketers make out the process of retailing as a necessary part of their overall distribution strategy.

\section{The Emerging Revolution:}

India's GDP growth of 8 per cent in 2008-09 is the highest posted for over 18 years, reflecting the booming economy of the country. Growing in tandem with the economy is the Indian retail sector. The sector is on a high growth trajectory and is expected to grow by more than 27 per cent over the next 5 to 6 years. Retail is one of India's largest industries, contributing to about 10 per cent of the GDP and providing employment to 8 per cent of the nation's workforce. Indian retail business promises to be one of the core sectors of the Indian economy, with organized retail sector estimated to grow by 400 per cent of its current size by 2010-11.

The growth and potential of the sector is being widely acknowledged both in the domestic as well as international forums. India topped AT Kearney's Global Retail Development Index 2009 for the third consecutive year, retaining its position in the global market as the most preferred retail destination amongst emerging markets. For the fifth time, India also topped the Global Consumer Confidence Index June - 2009 conducted twice a year by The Nielsen Company. Indians were judged the world's most optimistic consumers, with large sections of the population considering "now" a good time to spend.

\section{Objectives of the Study}

1. To elucidate the pattern of retail marketing in East Godavari District of Andhra Pradesh

2. To study the buying behavior of the customers in retail marketing.

3. To analyze the structure and growth of the retail marketing in type II cities

\section{Methodology:}


The discussion on the methodology, indicate how sampling method is used, how the data is ascertained, what statistical tools are used in the analysis and to sort out the limitations of the study. The methodology adopted for the study is descriptive and empirical. The purpose of studying trends in retailing, the concepts have been drawn from marketing theory and an attempt has been made to examine application of marketing strategies adopted by the retailer and also to analyze the emerging trends

Sampling:

Multi-stage stratified random sampling method is used in the present study.

\section{Selection of consumers:}

The last stage of sample consists of selection of consumers from the selected areas. About 252 consumers were randomly selected in this regard.

\section{Hypotheses:}

1. Formulate the (null) hypothesis $\left(\mathrm{H}_{0}\right)$ : There is difference between margins based

On different level products. Margin rate may be higher to less quality product and vice versa.

2. Alternative hypothesis (H1): There is no difference between margins based on different level products.

3. State the level of significance: It is stated that the correlation shows at 5 per cent level significant level of acceptance.

4. State the decision rule: The rule is - accept the null hypothesis $\left(\mathrm{H}_{\mathrm{o}}\right)$, if the

Calculated value of $\chi^{2}$ is less than the degrees of freedom (critical) value i.e., $\chi^{2-}$ table value. If calculated value is more than the table value, reject null hypothesis

$\left(\mathrm{H}_{0}\right)$ i.e., accept the alternative hypothesis $\left(\mathrm{H}_{1}\right)$.

\section{Data analysis:}

Table 1: Classification of consumers basing on purchasing, and their behavior

\begin{tabular}{|c|c|c|c|c|c|c|c|}
\hline \multicolumn{3}{|c|}{ Purchasing level/group } & \multicolumn{5}{|c|}{ Retailers view about Consumers } \\
\hline \multirow[t]{2}{*}{ Income group } & \multicolumn{2}{|c|}{ As per the retailers } & \multirow[b]{2}{*}{ Item } & \multicolumn{2}{|c|}{ Yes } & \multicolumn{2}{|c|}{ No } \\
\hline & Number & $\%$ & & Number & $\%$ & Number & $\%$ \\
\hline$>1500$ & 36 & 45 & $\begin{array}{l}\text { Change in Consumer } \\
\text { Behavior }\end{array}$ & 30 & 40.0 & 00 & 00.0 \\
\hline 1501 to 5000 & 24 & 30 & Improved awareness & 25 & 33.33 & 00 & 00.0 \\
\hline 5001 to 1000 & 14 & 17.5 & Change in loyalty & 20 & 26.67 & 05 & 100.0 \\
\hline Above 10001 & 6 & 7.5 & Total & 75 & 100.0 & 05 & 100.0 \\
\hline
\end{tabular}

Table 1 reveals the purchasing level and their changing behavior of consumer as per the perception of the retailers. It is clear from the table that, out of the total 80 retail shop owners, 45 per cent of retail shop owners have opined that the consumer purchasing level comes to above Rs. 1500 per month. About 30 per cent retailer expressed that the purchasing level comes to Rs 1501 to 5000 followed by 17.5 per cent under Rs 5001 to 10,000 and above Rs 10000 is the opinion of 7.5 per cent retailers. Towards the changing behavior of the consumer observed by the retailer is 30 retailer shop owners agreed that there is a fashionable change in consumer behavior. About 25 retailers observed that products awareness has been improved in the minds of the consumers. 20 respondents were observed regarding loyalty.

Table 2: Nature of publicity and sales man role in sales extension

\begin{tabular}{|l|c|c|c|c|c|}
\hline \multicolumn{1}{|c|}{ Nature of publicity } & \multicolumn{2}{c|}{ Sales man role in sales expansion } \\
\hline \multicolumn{1}{|c|}{ Item } & Number & percentage & Item & Number & percentage \\
\hline $\begin{array}{l}\text { No Public Relation } \\
\begin{array}{l}\text { Moderate Public } \\
\text { Relation }\end{array}\end{array}$ & 16 & 20.0 & Greater extent & 26 & 32.5 \\
\hline Nativity & 22 & 27.5 & Moderately & 0 & 0.0 \\
\hline Others & 42 & 52.5 & Very modest & 38 & 47.5 \\
\hline
\end{tabular}


Table 2 Indicates the nature of publicity use and sales man role in sales extension. About the nature of publicity, out of 80 retailers' 52.5 per cent respondents are giving their preference for nativity and followed by 27.5 per cent for modern public relations. It means the retailer act as a sales man and as a manager with the customers.

Salesman plays a significant role in sales promotion. Sales man's behavior, nature, relationship with customer, positive response motivation etc. promotes sales. The retailers' perception regarding the salesman role in sales expansion is greater extent as per the 32.5 per cent of respondents but 47.5 per cent of retailers felt that the salesman role is very modest and 20 per cent of retailer said that there is no impact of salesman in this regard.

Table 3: Marketing Strategy of Retailer on Services and Brand

\begin{tabular}{|c|c|c|c|c|c|c|c|c|}
\hline $\begin{array}{c}\text { Diversified } \\
\text { produced } \\
\& \text { sale }\end{array}$ & \multicolumn{4}{|c|}{ Services strategy } & \multicolumn{4}{|c|}{ Brand introduced } \\
\hline & Q \& Q & Packing & $\begin{array}{l}\text { Labeling, } \\
\text { brand }\end{array}$ & $\begin{array}{l}\text { All the } \\
\text { above }\end{array}$ & $\begin{array}{l}\text { Manufacture } \\
\text { brand }\end{array}$ & $\begin{array}{r}\text { own } \\
\text { brand }\end{array}$ & Both & $\begin{array}{l}\text { Other( } \\
\text { local) }\end{array}$ \\
\hline $\begin{array}{c}\text { Cereals, } \\
\text { pulses \& } \\
\text { grocery }\end{array}$ & $15(18.75)$ & $2(2.5)$ & $3(3.75)$ & $10(12.5)$ & $6(7.5)$ & $2(2.5)$ & $20(25.0)$ & 0 \\
\hline Medical & $4(5.0)$ & $8(10.0)$ & $10(12.5)$ & 0 & $21(26.25)$ & 0 & 0 & 0 \\
\hline FMCG & $2(2.5)$ & 0 & 0 & $\begin{array}{c}10 \\
(12.5)\end{array}$ & $8(10.0)$ & $2(2.5)$ & $10(12.5)$ & 0 \\
\hline $\begin{array}{l}\text { Perishable } \\
\text { items }\end{array}$ & $16(20.0)$ & 0 & 0 & 0 & 0 & $11(13.75)$ & 0 & 0 \\
\hline $\begin{array}{l}\text { Chi _- } \\
\text { square }\end{array}$ & \multicolumn{4}{|c|}{$\begin{array}{l}\text { Calculated value } 319.63 \\
\text { Table value } @ 9 \text { d.f } 16.92\end{array}$} & \multicolumn{4}{|c|}{$\begin{array}{l}\text { Calculated value } 105.96 \\
\text { Table value @ } 9 \text { d.f } 16.92\end{array}$} \\
\hline
\end{tabular}

Table 3 Marketing strategy to sales promotion is a very important factor to the retailer. It is observed in the study that there are various types of products like-cereals, pulses and grocery, medical, FMCG and perishable items are diversified for the sales. The retailers introducing new product of diversified sales products and followed Q\&Q, Packing, Labeling, Brand etc., services strategy. They also adopting brand strategies of introduced manufacturing brand, Own Brand, and both for sales maximization through attracting the consumers with brand introduce.

Above indicates the marketing strategy of retailer on sales of product, services and brand. With regard to introduce the new products in retailer shop, out of 80 respondents, 37.5 per cent of them are introduced up to 5 types of products of cereals, pulses and grocery items. About 12.5 of the retailers introduced up to 12 items including medical goods, basing on customer the requirements and their needs. In fast moving consumer goods (FMCG), less than five items are introduced new products by 10 respondents. These are 15 per cent of respondents introduced FMCG products from 6 to 10 and 7.5 per cent of them are also introduced new perishable items at same level. These goods are introduced as seasonal products. It is identified that the $\chi^{2}$ value 319.63 is more than table value 16.92. The difference of degree of freedom is recorded at 9 . Hence, rejected the null hypothesis.

To deliver the cereals, pulses and grocery items, 18.75 per cent of the respondents are following Q\&Q services strategy followed packing by 2.5 per cent of respondents, labeling by 3.75 respondents and 12.5 per cent of them are using all the above said services strategy in the study area. In case of medical, different methods like Q\&Q, Packing, Labeling, and brand services strategies have adopted by the retailers. Further, they are 12.5 per cent in case of FMCG items in this regard. It is identified that the $\chi^{2}$ value 105.96 is more than table value 16.92 . The difference of degree of freedom is recorded at 9 . Hence, rejected the null hypothesis @ 5 per cent level of significance and accepted alternative hypothesis. 


\section{Findings:}

1. Perceptions of customers regarding retailing explained in different dimensions. Many Cultural, Psychological, buying decisions and Process factors are influencing the customer purchasing behavior.

2. The pattern of change in buying behavior of respondents is more in salaried employees. Except 2.38 percent of the respondents, all the respondents' have changed their buying behavior in the last 2 years.

3. Marketing strategy to sales promotion is a very important factor to the retailer.

4. The customer preference is mainly to the quality and quantity, labeling, packing and manufacture brand and retailer's own brand only. There is no second thought in their minds.

\section{Suggestions:}

1. The nature and expansion of retailing depends on the consumer behavior.

2. The retailers have introducing new products like Q\&Q, Packing, Labeling, Brand etc., with service strategy. Majority of the respondents are offering schemes and coupons, drawn gift offers and direct sale to the consumer.

3. Advertising is most important in the making to the new market share.

4. Point of purchase is more important in the retail business.

5. Most of the customer is mostly seeing the brand and go to purchase, so that the retailer is most care about the brands.

\section{Conclusion:}

Retail is one of India's largest sectors, contributing to about 10 per cent of the GDP and providing employment to 8 per cent of the nation's workforce. Indian retail business promises to be one of the core sectors of the Indian economy. Salesman plays a significant role in sales promotion. Sales man's behavior, nature, relationship with customer, positive response motivation etc. promotes sales. The retailers' perception regarding the salesman role in sales expansion is greater extent.

\section{References:}

1. AT Kearney, "Emerging Market priorities for Global Retailers," 2009, 2011 Global Retail Development Index.

2. AT Kearney, "Retail in India Getting organized to drive growth", 2006.

3. Arif Sheikh, Kaneez fatimai, Retail management (2003), published by Himalaya publishing house.

4. Philip Kotler (2003); Marketing Management, Millennium Edition, prentice hall of India private limited.

5. A J Lamba (2002), The Art of Retailing Tata McGraw-Hill.

6. CR.Kothari: (2009.)Research Methodology methods and techniques, New Age international publishers, New Delhi.

7. Dipak Kumar Bhattacharyya (2010), Research Methodology,Excel Books,New Delhi

8. R.Panneerselvam( (2 013 ), Res e arch Methodology,PHI,Haryana. 